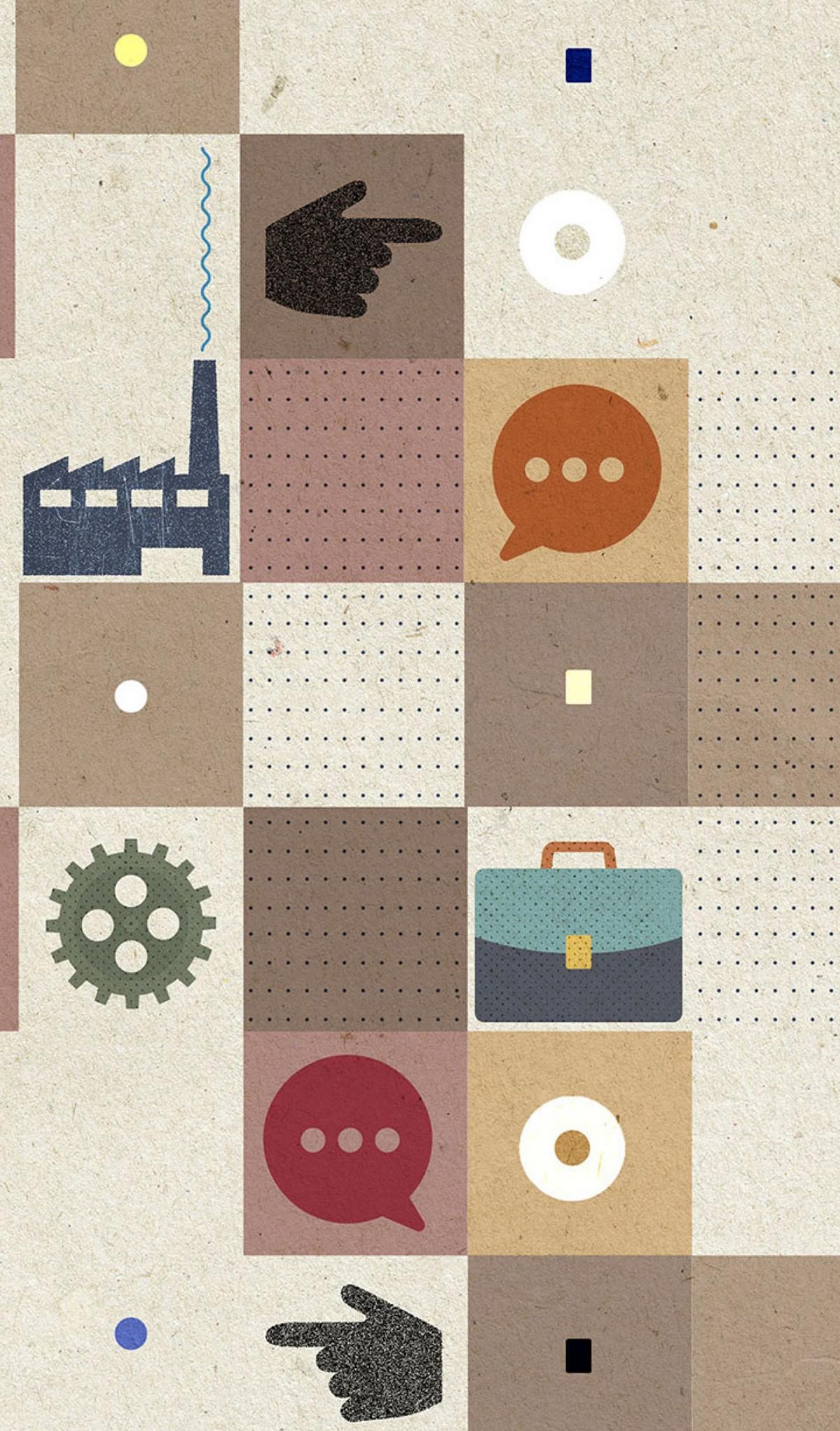




\title{
O liberal-desenvolvimentismo da FIESP nos governos do PT: a construção pragmática de uma agenda político-econômica ${ }^{1}$
}

\author{
FIESP'S liberal developmentalism in the PT \\ governments: The pragmatic construction \\ of a political and economic agenda
}

Francisco José Mendes Duarte*

Resumo

Após ter reivindicado as políticas econômicas que contribuíram para o fracasso do governo Dilma, a Fiesp participou da derrubada da presidente e da formulação da agenda ultra liberal que alçou Temer ao poder. Este comportamento expôs o pragmatismo histórico da Fiesp, que busca alianças para alcançar seus interesses, mas não hesita em rompê-las, com certa autonomia, a depender do contexto. Para testar essa tese, recuamos aos governos Lula e analisamos como o pragmatismo e a busca por autonomia contribuem na construção da agenda da Fiesp. Abordamos, qualitativamente, fontes primárias e secundárias. Sem partido definido, a Fiesp tem uma agenda ancorada na convenção liberal-desenvolvimentista, que pendula entre pautas desenvolvimentistas e neoliberais. O comportamento pendular da Fiesp é sensível às conjunturas. Na década passada, diante do pacto lulista e da retomada do crescimento, movimentou-se moderadamente. Nesta década, com a queda das taxas de lucro e a crescente desindustrialização, acompanhou a radicalização dos abastados.

Palavras-chaves: Agenda da Fiesp; liberal-desenvolvimentismo; convenções do desenvolvimento; pragmatismo; governos do Partido dos Trabalhadores.

\begin{abstract}
After claiming economic policies that contributed to the failure of the Dilma's government, Fiesp participated in the overthrow of the president and in the formulation of the ultra-liberal agenda that brought Temer to power.This behavior exposed Fiesp's historical pragmatism, which seeks alliances to reach its interests, but does not hesitate to break them, with a certain autonomy, depending on the conjuncture. To test this thesis, we went back to the Lula's governments and analyzed the role of pragmatism and relative autonomy in building the Fiesp agenda. We qualitatively approach primary and secondary sources. Without a defined party, Fiesp has an agenda anchored in the liberal-developmentalistconvention, which hangs between developmental and neoliberal agendas.Fiesp'spendular behavior is sensitive to conjunctures.In the past decade, in the face of the Lula's deal and the resumption of growth, it hung moderately.In this decade, with falling profit rates and growing deindustrialization, it accompanied the radicalization of the effluents.
\end{abstract}

Keywords: Fiesp's Agenda; liberal-developmentalism; development conventions; pragmatism; governments of the Workers' Party

\footnotetext{
* Doutor em Política Social e professor do Programa de Pós-graduação em Políticas Públicas, Estratégias e Desenvolvimento, Instituto de Economia, Universidade Federal do Rio de Janeiro. https://orcid.org/0000-0001-9178-3458. E-mail: franciscomduarte85@gmail.com
}

http://dx.doi.org/10.51861/ded.dmv.1.003 


\section{INTRODUÇÂO}

O presente texto toma a luta em torno do contestável ${ }^{2}$ impeachment de Dilma Rousseff, do Partido dos Trabalhadores (PT), como ponto de partida para compreender a agenda político-econômica da Federação das Indústrias do Estado de São Paulo (FIESP) ${ }^{3}$.

Há pelo menos duas décadas o chamado "custo Brasil", conjunto de fatores que reduz a competitividade da indústria brasileira, é o elemento central da agenda político-econômica da Fiesp, que busca revertê-lo atuando, principalmente, em quatro frentes: 1) na redução das taxas de juros, visando ao equilíbrio entre a estabilidade monetária e o crescimento econômico; 2) na consolidação de uma taxa de câmbio que permita a integração competitivada indústria nas cadeias globais; 3) na implementação de reformas estruturais, sobretudo a previdenciária, com vistas a reduzir drasticamente os gastos públicos, compreendidos como um obstáculo à queda das taxas de juros e à liberação de recursos para investimentos em infraestrutura; e 4) na formação de uma política comercial que abra os principais mercados globais para o Brasil.

Dito isto, sustentamos que a Fiesp propôs e apoiou algumas das medidas econômicas do governo de Dilma Rousseff, entre 2011 e 2013, por entender que estas poderiam reverter as elevadas taxas de juros e a apreciação cambial que reduziam a competitividade da indústria. Contudo, uma vez fracassadas as medidas da presidente, a Federação, de forma pragmática, viu no programa "Uma Ponte para o Futuro", que alçou o vice-presidente Michel Temer à presidência, uma oportunidade para alcançar a outra parte de sua agenda, a das grandes reformas liberais.

A nossa hipótese é que tal comportamento pendular da Fiesp reafirm a a tese defendida por cientistas políticos, como Diniz (1978), Boschi (1979) e Leopoldi (2000) e Bianchi (2004; 2015), de que o empresariado industrial, sobretudo o paulista, busca construir alianças para avançar sua agenda de desenvolvimento, mas não hesita em rompê-las, com certa autonomia e enorme pragmatismo, diante dos constrangimentos políticos e econômicos que se impóem ao Brasil. Logo, o pragmatismo e a relativa autonomia dos industriais seriam os dinamizadores de seu comportamento pendular diante do governo Dilma.

Para testar essa tese, escapamos das tensões que envolveram a derrubada de Dilma e recuamos ao governo Lula (2003-2010). Nele, analisamos como o pragmatismo e a busca por autonomia contribuem na construção da agenda da Fiesp.

Em termos teóricos, entendemos que três visóes do desenvolvimento o neoliberalismo, o liberal-desenvolvimentismo e o estatal-distributivismo 
estiveram em disputa no Brasil entre meados das décadas de 1990 e de 2010 (SALLUM JR. e GOULART, 2016). O projeto político-econômico da Fiesp, compartilhado por setores da elite política e intelectual, está alinhado ao liberal-desenvolvimentismo (BIANCHI, 2004).

Essas três visões são compreendidas aqui como convençôes de desenvolvimento. Entendemos o desenvolvimento como uma articulação institucional, sobretudo, entre Estado e mercados, pautada por regras e normas que visam alcançar o crescimento e a transformação da estrutura socioeconômica de uma sociedade. Neste sentido, uma convenção do desenvolvimento é a expressão desse conjunto de regras no comportamento e nas formas de compreender de indivíduos e atores coletivos (ERBER, 2011). Além de incorporadas, as convençốes são interpretadas e criticadas (NIEDERLE, 2013). Logo, a busca pelo desenvolvimento instaura conflitos entre convençóes, parcialmente divergentes, pela definição da agenda de problemas a serem superados por um dado país (ERBER, 2011).

As convençôes do desenvolvimento, para se consolidarem, precisam estar respaldadas em conhecimentos formais, codificados em teorias econômicas, políticas e sociais, e informais, presentes no imaginário social; se ancorar em coalizóes de interesses, que reúnam partidos, fraçóes do empresariado e da classe trabalhadora, entre outros; e implementar políticas cujos resultados legitimem a sua narrativa histórica (ERBER, 2011).

Dotados desse referencial teórico, analisamos a agenda da Fiesp a partir de seu posicionamento diante das políticas macroeconômica, externa e de comércio exterior nos governos de Lula. Ao fazê-lo, descrevemos, ainda que parcialmente, a construção da convenção liberal-desenvolvimentista e suas clivagens com as outras convençóes.

Com vistas a alcançar esses objetivos, ao modo de um trabalho historiográfico, fazemos uma análise qualitativa de fontes primárias e secundárias. Dentre as fontes primárias, foram consultados a Revista da Induistria (20042010), periódico mensal da Fiesp, e reportagens e documentos publicados no sítio da organização. Quanto às fontes secundárias, foram utilizadas reportagens de jornais, como Estadão, Folha de São Paulo, O Globo e Valor Econômico e Estado de Minas; de revistas, como Carta Capital, Época, Istoé e Piaui; de portais de notícia, como G1, Uol, BBC Brasil e El País Brasil; e os sítios da Câmara dos Deputados e do Senado.

O texto se organiza da seguinte forma. Na primeira seção tratamos do comportamento da Fiesp no contexto do impeachment de Dilma Rousseff. $\mathrm{Na}$ segunda seção, abordamos o debate sobre o comportamento ambíguo do empresariado industrial diante do governo Dilma, expomos algumas teses formuladas neste debate e nos posicionamos em relação a elas. $\mathrm{Na}$ terceira 
seção, demonstramos como as críticas endereçadas à convenção neoliberal pelas convenções liberal-desenvolvimentista e estatal-distributivista permitiram a aproximação entre essas últimas e deram base à coalizão que levou Lula à presidência. Nas quarta e na quinta seçôes, abordamos o comportamento da Fiesp ao longo dos governos Lula para demonstrar como tanto o antimonetarismo, que a aproximou de Dilma, quanto o fiscalismo, que a aproximou de Temer, já estavam no centro da "agenda Fiesp” na década passada e que para impulsionar essas demandas os industriais paulistas pendulavam, pragmaticamente, entre as convenções neoliberal e estatal-distributivista. $\mathrm{Na}$ conclusão, sintetizamos os argumentos delineados no texto e formulamos, a partir do conceito de efeito túnel, uma hipótese explicativa para o "desastre do desenvolvimento" em curso no Brasil.

\section{A FIESP NO JOGO SUJO DO IMPEACHMENT}

Antes mesmo da corrida presidencial de 2014, muitos empresários já se revelavam insatisfeitos com a política econômica implementada pelo governo Dilma e com a indisposição da presidente para o diálogo ${ }^{4}$.

A Fiesp, por sua vez, reivindicou muitas das medidas da"nova matriz econômica” (NME) - que visava reduzir as taxas de juros e as tarifas de energia elétrica ${ }^{5}$, desvalorizar o câmbio, desonerar tributos e conceder créditos subsidiados e a execução de serviços públicos para a iniciativa privada - implementada pelo governo Dilma entre 2011 e $2013^{6}$ (SINGER, 2015; BASTOS, 2017). Entretanto, durante a eleição de 2014, no qual a NME foi alvo de intensas críticas, advindas, principalmente, de grandes empresários e economistas ortodoxos (CARVALHO, 2018; BASTOS, 2017), a Fiesp começou a se afastar do governo ${ }^{7}$.

Apesar de Dilma ter vencido nas urnas, formou-se um consenso de que a expansão fiscal implementada pelo seu governo era a principal responsável pela deterioração das contas públicas. Dilma, pressionada, adotou a agenda do ajuste fiscal defendida por Aécio Neves (PSDB) na campanha e apoiada pelo empresariado (CARVALHO, 2018; IANONI, 2018) ${ }^{8}$.

A oposição não se arrefeceu, entretanto. Primeiro, com base em frágeis denúncias de fraude, o PSDB pediu ao Tribunal Eleitoral uma auditoria das urnas?. Sem sucesso, os tucanos pediram a cassação da chapa de Dilma com bases em delações feitas por executivos da Petrobras presos pela Operação Lava-Jato $(\mathrm{LJ})^{10}$. As delaçóes "vazavam como uma peneira ${ }^{11}$ " e contribuíam para desestabilizar o novo governo. Impulsionados pela atuação antidemocrática do PSDB e da LJ ${ }^{12}$, novos movimentos de direita, a exemplo do Movimento Brasil Livre (MBL), desencadearam grandes protestos em favor do 
impeachment da presidente. Essa dinâmica se arrastou por todo ano de 2015 até meados de 2016. (SINGER, 2018).

Ao longo de 2015, Dilma tornou-se cada vez mais dependente do $\mathrm{PMDB}^{13}$ para aprovar as medidas necessárias ao ajuste fiscal. Na Câmara dos Deputados, o pemedebista Eduardo Cunha, que derrotara o governo na disputa pela presidência da Casa, boicotava o ajuste sempre que se sentia contrariado. Em abril, Temer (PSDB) passou a intermediar o diálogo entre o Planalto e Cunha. Nessa função, o vice-presidente acumulou forças para se viabilizar como alternativa à Dilma. Esta estratégia ficou clara quando, diante das ameaças de aprovação das chamadas "pautas bombas" na Câmara, que poderiam agravar ainda mais o desequilíbrio do orçamento, Temer afirmou publicamente que era necessário "encontrar alguém capaz de reunir a todos”. Dilma não era esse alguém ${ }^{14}$.

Entre agosto e setembro, o grande empresariado, preocupado com o andamento do ajuste fiscal, buscou atenuar os conflitos. À Folha de São Paulo, Roberto Setúbal, presidente do banco Itaú, afirmou que não via razóes para o impeachment da presidente ${ }^{15}$. Em nota, a Fiesp e a Firjan endossaram o pronunciamento público do vice-presidente, compreendido como um chamamento à responsabilidade institucional para a aprovação das medidas de ajuste fiscal ${ }^{16}$. No entanto, Temer dobrou a aposta ao afirmar que Dilma dificilmente completaria o mandato com uma popularidade tão baixa ${ }^{17}$.

No final de setembro, a agência de rating Standard and Poor's rebaixou a nota de crédito do Brasil, retirando-lhe o selo de "bom pagador"18. Este era um dos temores do grande empresariado ${ }^{19}$. O papel moderador que este ator exercia até então foi rompido pela Fiesp.

Desde o início do ano, a Fiesp argumentava que o ajuste fiscal deveria ser alcançado via cortes de despesas públicas e não por meio do aumento da arrecadação $\mathrm{O}^{20}$. Em outubro, quando a proposta de recriação da Contribuição Provisória sobre Movimentação Financeira (CPMF) tornou-se o centro da estratégia de ajuste fiscal, a entidadelançou a campanha "Não vou pagar o pato" contra o aumento dos impostos. O símbolo da campanha, um pato inflável de grandes proporçóes, foi instalado em frente ao Congresso Nacional. Nesta ocasião, Paulo Skaf declarou: "O governo tem um tamanho maior que deveria ter... não tem eficiência, cheio de burocracia... e mesmo arrecadando falta dinheiro. Agora a questão da CPMF vai caminhar, a sociedade já disse não em 2007, e o governo insiste. "21.

No final de outubro, o PMDB lançaria o plano "Uma ponte para o futuro". Encomendado por Michel Temer, o plano estabelecia diretrizes neoliberais para as reformas da previdência e do sistema tributário e previa 
um amplo programa de privatizaçóes ${ }^{22}$. As propostas foram formuladas por Roberto Brant, ex-ministro de Cardoso (1995-2002), que contou com a contribuição de José Serra (PSDB), de economistas conservadores, como Marcos Lisboa e Delfim Netto, e da própria Fiesp. O plano foi apresentado a empresários do eixo Rio-São Paulo ${ }^{23}$.

Às articulações golpistas de Temer somavam-se as chantagens de Cunha. Em novembro, para evitar sua cassação no Conselho de Ética da Câmara, por ter mentido perante a CPI da Petrobras, Cunha ofereceu ao governo uma trégua: se os deputados petistas votassem a seu favor no Conselho, ele engavetaria os pedidos de impeachment e ajudaria no encaminhamento do ajuste. Contudo, em 2 de dezembro, os petistas afirmaram que votariam contra Cunha e o governo conseguiu aprovar, no Senado, a mudança da meta fiscal de 2015. Cunha contra-atacou com a abertura de um dos processos de impeachment que tinha em mãos ${ }^{24}$. A aposta era de que a ascensão de Temer à presidência promoveria as reformas estruturais necessárias ao ajuste, desejo maior dos empresários ${ }^{25}$, e apaziguaria a sanha justiceira da Lava-Jato, desejo incontido de muitos políticos ${ }^{26}$. A Fiesp apostou alto nessa jogada.

No dia 14 de dezembro de 2015, Paulo Skaf anunciou o apoio formal da Fiesp ao impeachment e o justificou com base nas dificuldades do governo em aprovar o ajuste fiscal prometido e na perspectiva de "estouro" do orçamento para o ano seguinte ${ }^{27}$.

O envolvimento da Fiesp na derrubada de Dilma foi bem além do apoio formal. Em março de 2016, sob a liderança da Fiesp, entidades empresariais publicaram nos principais jornais do país um anúncio com o slogan Impeachment Já!. O anúncio trazia o seguinte texto: [...] Dizer SIM ao impeachment, dentro dos parâmetros constitucionais, é dizer NÃO ao descontrole econômico, ao descaso com as empresas, com o emprego e, principalmente com você. Chega de pagar o pato $[\ldots]^{28}$. Nas entrelinhas, o texto do anúncio buscava rechaçar a ideia de que o impeachment era um golpe disfarçado, argumento sustentado pelos apoiadores da presidente, e legitimar o processo devido à crise econômica gerada pelo governo.

O engajamento da Fiesp no impeachment lançou suspeitas sobre os reais interesses de Skaf, filiado ao PMDB e próximo a Temer, no processo. Segundo reportagem do Valor Econômico, de forma reservada, muitos empresários declaravam não concordar com a liderança assumida pela Fiesp no movimento. A mesma reportagem destacou que Benjamin Steinbruch, vicepresidente da Fiesp, não participara das decisóes que levaram ao apoio do impeachment e que o senador Armando Monteiro, ex-presidente da Confederação Nacional da Indústria (CNI) e ministro do governo Dilma Rousseff, 
criticara Skaf por expor a Fiesp para alcançar objetivos políticos. Ao jornal, Skaf afirmou que atuava em nome das bases da Federação ${ }^{29}$.

Alguns acadêmicos arriscaram análises mais amplas sobre a relação ambígua da Fiesp com o governo Dilma.

\section{A RETOMADA DO DEBATE SOBRE O COMPORTAMENTO POLÍTICO-ECONÔMICO DO EMPRESARIADO INDUSTRIAL}

André Singer (2015) levantou a hipótese de que o afastamento paulatino dos industriais em relação ao governo Dilma era o principal responsável pelo fracasso da NME. Segundo Singer, tal afastamento teve início no final de 2012, quando lideranças industriais, sobretudo a Fiesp, voltaram a reivindicar reformas para a redução dos custos da mão-de-obra, passaram a criticar a política externa de Cooperação Sul-Sul e apoiar uma maior integração do país aos interesses estadunidenses.

Sem ignorar a importância das explicações conjunturais, Singer formulou uma interpretação histórico-estrutural para a questão. Ele destacou que os interesses da burguesia industrial sempre pendularam no Brasil e no governo Dilma ocorreu o mesmo. No primeiro momento, os industriais alinharamse aos interesses das classes populares pela maior intervenção do Estado na economia. $\mathrm{O}$ que se revelou na formulação, pela Fiesp e pelas centrais sindicais, do documento Brasil do diálogo, da produção e do emprego (2011). Em seguida, ao perceberem o perigoso fortalecimento do Estado e dos sindicatos de trabalhadores, os industriais mudaram de posição se aproximando dos interesses do bloco rentista em contradição com seus próprios interesses. Dilma, assim como ocorrera no Golpe civil-militar de 1964, não foi capaz de mobilizar as bases sociais para defender o seu projeto de desenvolvimento do "mecanismo burguês pendular".

Apesar dos incontestáveis méritos do artigo de Singer (2015), que recuperou o debate sobre o papel dos industriais no desenvolvimento brasileiro, temos duas críticas às suas conclusóes. Primeiro, o autor exagera ao afirmar que o alinhamento ao bloco rentista vai contra os interesses dos industriais. Pelo contrário, como veremos na atuação da Fiesp no governo Lula, o comportamento pendular dos industriais atende a interesses, de curto-prazo, bastante concretos. Segundo, Singer lança uma tese verdadeira, a de que o empresariado industrial, sobretudo a Fiesp, foi ingrato com o governo Dilma, mas de poder analítico limitado (BIANCHI, 2015). Voltamos a este ponto adiante.

Laura Carvalho (2018), por sua vez, argumenta que a Nova Matriz Econômica (NME), a qual se refere, ironicamente, pela alcunha de "agenda 
Fiesp", atendeu a propostas da federação paulista e levou o governo, em um contexto de recuo da demanda, a buscar a reversão do ciclo não através de investimentos públicos, mas por meio de incentivos ao investimento privado. Essa política equivocada, segundo a autora, permitiu a manutenção de baixos níveis de desemprego por algum tempo, mas teve pouco efeito na retomada do crescimento e, mesmo sem pretendê-lo, desencadeou um processo de concentração de renda. Logo, Carvalho rechaça o caráter positivo, que vigora na análise de Singer, das medidas ensejadas pelo governo Dilma, mas concorda com a tese do autor acerca da ingratidão da Fiesp. Para a autora, a Fiesp cooptou o governo para sua agenda e deu as costas a ele quando esta fracassou.

Por fim, Álvaro Bianchi (2015) formulou tese bastante esclarecedora sobre o engajamento da Fiesp no processo de impeachment:

[...] os industriais são mais pragmáticos do que ideológicos... costumam agir guiados pelos resultados no curto prazo e... tendem a adiar a tomada de uma posição política, embora ao contrário dos banqueiros, costumem em algum momento tomar partido.... Deixaram de acreditar que o atual governo seja capaz de reestabelecer uma dinâmica de crescimento econômico, por meio de um ajuste fiscal e da reforma trabalhista que consideram necessárias. ... Não estão dispostos a esperar por uma vitória da oposição em 2016 e desejam uma solução imediata para esta crise, a qual passa pelo PMDB paulista e pela liderança de Michel Temer $^{30}$.

Logo, para Bianchi (2015), é o pragmatismo histórico dos industriais paulistas que melhor explica seu apoio ao impeachment. Afinal, continua o autor, o governo Dilma demonstrava-se incapaz de implementar o ajuste fiscal e as reformas estruturais, dolorosos para a classe trabalhadora e para o subproletariado, que os industriais reivindicavam há tempos. Quanto à tese da ingratidão, afirma Bianchi (2015), ela serve apenas para explicar o que os industriais não deveriam fazer, romper com um governo que atendeu às suas demandas, mas não o que fizeram, apoiar o impeachment.

Concordamos com a tese de que é o pragmatismo da Fiesp que explica melhor a sua ruptura com o governo. Entretanto, endossar essa tese não significa negar o veio profundamente conservador, e mesmo reacionário, do empresariado industrial ou a significativa integração de interesses que ele mantém como capital financeiro. Mas sim, que mesmo mobilizado por seu conservadorismo atávico e constrangido por seu caráter dependente, o empresariado industrial busca, pragmaticamente, aumentar seu grau de autonomia e, com isso, ditar o ritmo e os termos do desenvolvimento.

Estes argumentos se sustentam, por exemplo, no fato de que Fiesp aderiu ao neoliberalismo radical do Plano Temer $^{31}$, mas não o fez sem críticas. 
No início de 2017, por exemplo, Skaf criticou, em artigo de jornal, a decisão da Petrobras, sob o governo Temer, de convidar unicamente empresas estrangeiras para participar da licitação do Comperj, complexo petroquímico na região metropolitana do Rio de Janeiro. No artigo, ele defendeu abertamente a política de conteúdo nacional vigente entre 2004 e $2014^{32}$. $\mathrm{Na}$ mesma semana, Steinbruch argumentou que, diante da onda protecionista iniciada por Trump, era necessário “... repensar o ingênuo receituário neoliberal que propóe a abertura irrestrita do pais... sem apoio e proteção de nenhuma natureza para o capital nacional 33 ".

As críticas da Fiesp ao governo Temer corroboram a seguinte colocação de Bianchi (2015): "Os industriais não têm um partido, mas usam todos de acordo com as circunstâncias”. Para sustentar esse argumento, analisamos o comportamento da Fiesp diante das politicas econômica e externas no governo Lula.

\section{AS CONVENÇÕES DO DESENVOLVIMENTO E A CHEGADA DE LULA AO PODER}

Ao longo dos anos 1990, a convenção neoliberal estabeleceu uma metáfora histórica que responsabilizava a burocracia estatal e os industriais, atores que sustentavam o nacional-desenvolvimentismo, pelo atraso econômico do país (ERBER, 2002). Embora tenham aderido, parcialmente, a esta convenção, apoiando as privatizaçóes e o desmonte do Estado de bem-estar, muitos segmentos industriais contestaram as baixas taxas de crescimento, os desequilíbrios externos e a destruiçãa de setores industriais desencadeada pela liberalização financeira e comercial (DINIZ e BOSCHI, 2004).

$\mathrm{Na}$ esteira dessa insatisfação, os industriais, especialmente os paulistas, e economistas, como Luiz Carlos Bresser-Pereira e José Serra, que compunham o governo do PSDB, mas eram críticos do neoliberalismo ortodoxo, começaram a formular, em separado e de modo pouco sistemático, a convenção liberal-desenvolvimentista ${ }^{34}$. Sem romper com a ideia, cara à convenção neoliberal, de transferir para o setor privado o protagonismo do desenvolvimento, os liberais-desenvolvimentistas buscavam, simultaneamente, manter a estabilidade monetária e retomar os investimentos e o crescimento econômico. Por outro lado, o PT, movimentos sociais e segmentos intelectuais priorizavam a consolidação dos direitos políticos e sociais previstos na Constituição, em detrimento da estabilização. Os economistas desse campo político, ligados principalmente à Unicamp e à UFRJ, buscavam reformular o Estado desenvolvimentista para capacitá-lo a protagonizar um processo de 
crescimento econômico com massiva inclusão social. Esta vertente oposicionista deu origem à convenção estatal-distributivista (SALLUM JR, 2013; SALLUM JR. E GOULART, 2016).

Portanto, no final dos anos de 1990, os fracassos da convenção neoliberal, sustentada principalmente pelo sistema financeiro, abriam espaço à consolidação e aproximação das convençôes liberal-desenvolvimentista e estatal-distributivista, ambas preocupadas com o esgarçamento da base produtiva. Não por acaso, Lula da Silva chegara ao poder, em 2003, acompanhado de um vice-presidente, José Alencar, proveniente da indústria têxtil, uma das mais esgarçadas com a abertura comercial.

Entretanto, não houve ruptura com o neoliberalismo. Primeiro, com vistas à redução da resistência do mercado financeiro, o governo Lula aderiu ao tripé macroeconômico, que abarca o câmbio flutuante e as metas de inflação e de superávit primário. Em seguida, nomeou uma equipe ministerial que expressava, claramente, uma tentativa de conciliação entre as agendas das três convençôes que disputavam os rumos do desenvolvimento nacional. A equipe era composta por neoliberais ortodoxos, como Antônio Palocci (Fazenda) e Henriques Meirelles (Banco Central); por liberais-desenvolvimentistas, como os empresários Luiz Fernando Furlan (Desenvolvimento) ${ }^{35}$ e Roberto Rodrigues (Agricultura) ${ }^{36}$; e por estatal-distributivistas, como Guido Mantega (Planejamento), Carlos Lessa (BNDES) e Celso Amorim (Relações Exteriores) (SALLUM JR. E GOULART, 2016).

\section{A FIESP NO INÍCIO DO GOVERNO LULA (2003-2004): EM BUSCA DE UMA "AUTONOMIA INSERIDA".}

Ao longo de 2003, o desapontamento da Fiesp com a política econômica ortodoxa adotada pelo governo levou o seu então presidente Horácio Piva a criticara política monetária. Ele também contestou o aumento da carga tributária e reivindicou metas para retomada do crescimento econômico ${ }^{37}$.

A Fiesp não estava sozinha em suas críticas. $\mathrm{O}$ industrial e vice-presidente José Alencar, ao longo dos dois mandatos de Lula, costumava argumentar que as taxas de juros eram uma questão mais política do que técnica e que o BC poderia, perfeitamente, adotar taxas de mercado ${ }^{38}$.

Contudo, foi o economista Carlos Lessa, representante do estatal-distributivismo, que protagonizou as principais tensóes entre as convençóes concorrentes. Por um lado, ele engrossava a crítica dos industriais aos juros elevados praticados pelo BC de Meirelles ${ }^{39}$. Por outro lado, o seu nacionalismo de viés estatista incomodava os liberais-desenvolvimentistas. Esse conflito expressou-se, por exemplo, na querela sobre a venda de açóes da Vale 
para a japonesa Mitsui. Enquanto Lessa queria exercer o direito de compra do BNDES para impedir que os japoneses conquistassem poder de veto no Conselho Administrativo da empresa brasileira, Furlan e Mantega não queriam intervir na transação ${ }^{40}$.

Esta dinâmica conflitiva durou até novembro de 2004, quando, por pressóes de Palocci, Meirelles e Furlan, Lessa foi demitido do cargo ${ }^{41}$. A queda de Lessa dividiu as opiniões dos empresários industriais. Newton de Mello, presidente da Associação Brasileira da Indústria de Máquinas e Equipamentos (Abimaq), lamentou a demissão de Lessa, dada a sua relevante postura nacionalista e sua crítica aos excessos de zelo com a inflação e ao descaso com o crescimento. Já Paulo Skaf, então recém-eleito presidente da Fiesp, foi mais moderado, elogiando tanto Lessa quanto o seu sucessor, Mantega ${ }^{42}$.

Com a ascensão de Skaf à presidência da Federação, a entidade elevou o tom de suas críticas à política externa, contestando o suposto privilégio dado pelo governo Lula às negociaçóes envolvendo os países do Sul, em detrimento dos países ricos do Norte ${ }^{43}$.

À primeira vista, isto pode parecer estranho, já que quadros da alta cúpula do governo federal, como o vice-presidente José Alencar, os ministros Antônio Palocci e José Dirceu e o senador petista Aloízio Mercadante, atuaram "arduamente" para que Skaf saísse vitorioso da eleição para presidente da Fiesp ${ }^{44}$. Entretanto, o fato é que Skaf buscou inserir a Fiesp nas redes políticas, sem perder sua relativa autonomia.

Essa estratégia de autonomia inserida - usamos, de forma livre, o conceito consagrado por Evans (2004) (5 $^{4}$ - ficaria mais explícita na nomeação, para os conselhos superiores e departamentos da Fiesp, de políticos e intelectuais ligados ao PSDB. Paulo Renato de Souza, ex-ministro da Educação de Cardoso, assumiu a direção do Conselho de Reponsabilidade Social; Roberto Giannetti, que também participara na gestão do PSDB, assumiu o Departamento de Relaçóes Internacionais e Comércio Exterior; e Rubens Barbosa, diplomata de carreira próximo ao PSDB, tornou-se presidente do Conselho Superior de Comércio Exterior da Fiesp.Para o Conselho Superior de Economia da Fiesp, foi nomeado o economista e então deputado federal Delfim Netto ${ }^{46}$, um dos promotores do liberal-desenvolvimentismo ${ }^{47}$ e importante interlocutor da Fiesp há décadas ${ }^{48}$.

A Fiesp, portanto, mantinha-se próxima do governo federal, mas não deixava de criticá-lo e nem mesmo de abrigar pessoas próximas ao PSDB em seu quadro interno. A entidade transitava, pragmaticamente, tanto nos círculos da classe política mais alinhados à convenção neoliberal quanto naqueles mais alinhados à convenção estatal-redistributivista. 


\section{A Fiesp e a política macroeconômica (2004-2006)}

Em dezembro de 2004, uma reportagem da Revista da Indústria comparava os níveis das taxas de juros, do spread bancário e da carga tributária do Brasil com os de outros países latino-americanos, como Argentina e Chile, e destacava nosso mau desempenho (REVISTA DA INDÚSTRIA, dez., 2004). Para a Fiesp, ao demandar crédito continuamente do sistema financeiro, o governo brasileiro fazia com que o patamar dos juros se elevasse e, com isso, encarecia o crédito para o setor produtivo. Além disso, a escalada dos juros encarecia o serviço da dívida pública, o que levava o governo a recorrer ao aumento de impostos. Logo, a federação entendia que o governo precisava fazer um duro ajuste fiscal, capaz de reduzir a dívida pública e, com isso, acelerar a queda das taxas de juros ${ }^{49}$.

Em abril de 2005, a Fiesp apresentou um estudo que demonstrava que os preços monitorados, relacionados a atividades próprias do governo, como petróleo, transporte, educação e planos de saúde, e responsáveis por $40 \%$ inflação, são imunes aos aumentos da Taxa Selic. Diante do dado, o Diretor do Departamento de Pesquisas Econômicas da Fiesp, Paulo Francini, criticou o sistema de metas inflacionárias adotado por perseguir o centro da meta em espaços de tempo muito curtos e, com isso, afetar gravemente o nível de expansão das atividades produtivas. Para Francini, as metas de inflação irrealistas deviam-se ao viés monetarista do $\mathrm{BC}^{50}$. Skaf, por sua vez, evitou sugerir uma intervenção direta nos juros e enfatizou que o foco da Fiesp era o combate à "doença chamada gasto público" (REVISTA DA INDÚSTRIA, abr., 2005, p. 27).

As críticas distintas de Skaf, focada na política fiscal, e de Francini, focada na política monetária, revelam o caráter ambíguo da agenda macroeconômica da Fiesp. Por um lado, lutava com firmeza pela redução dos gastos públicos. Por outro, conduzia, com maior cautela, uma crítica ao viés ideológico da política monetária. Esta cautela devia-se, certamente, à força do núcleo neoliberal no governo e, talvez, ao fato de que parcela dos industriais lucrasse com operações financeiras favorecidas pelas taxas de juros elevadas. Vejamos.

Em fevereiro de 2005, a Fiesp, junto com outras organizaçóes empresariais, como a CNI, realizou um ato público em protesto contra a MP 232, que previa a ampliação da base de cálculo do IR e da CSLL das empresas prestadoras de serviços de $32 \%$ para $40 \%$. Preocupada com os efeitos do aumento de impostos na cadeia produtiva, a federação paulista cobrou do Estado "mal gastador" mais eficiência nos gastos ${ }^{51}$.

Em meio à mobilização contra a MP 232, Skaf expôs a face mais liberal da agenda da entidade: "reforma tributária que desonere a produção, reforma trabalhista que permita aumentar a renda dos trabalbadores... responsabi- 
lidade fiscal que possibilite juros menores... e câmbio realista. ... A Nação é maior do que o Estado" (REVISTA DA INDÚSTRIA, fev. 2005, p. 34). Esta passagem também revela o caráter ideológico das convençóes de desenvolvimento que buscam a integração de interesses, por exemplo, entre classes antagônicas.

No segundo semestre de 2005, Delfim Netto (PP-SP) elaborou uma proposta para solucionar o descontrole do déficit público e, consequentemente, das elevadas taxas de juros que impediam a retomada do crescimento sustentado. Ele propunha o congelamento dos gastos de custeio do governo por cinco anos, período em que os gastos só poderiam acompanhar a correção da inflação e não a do PIB e um "choque de gestão" nos setores menos eficientes do governo, aqueles protegidos pela vinculação de receitas, como a Saúde, a Educação e a Previdência. Além disso, Delfim defendia que o ajuste fosse institucionalizado via emenda constitucional: "A credibilidade vem com uma emenda... determinando que as Leis de Diretrizes Orçamentárias (LDOs) dos próximos cinco anos providenciarão superávits primários para eliminar o déficit nominal até 2008 ou 2010"(REVISTA DA INDÚSTRIA, jul., 2005, p. 18).

Tal proposta confrontava-se diretamente com o estatal-distributivismo, do PT e de movimentos sociais, que reconhecem nas vinculações constitucionais um mecanismo fundamental para financiar as políticas sociais. Não por acaso, vinte deputados do partido repudiaram a proposta por meio de uma nota pública, antes de um jantar promovido pela Fiesp para discuti-la com membros do governo ${ }^{52}$.

A proposta da Fiesp para o ajuste, apresentada a Palocci no mesmo mês, era um pouco diferente. Previa a redução nos gastos de $2 \%$ reais ao ano durante seis anos seguidos e a manutenção do nível total de gastos pelos quatro anos seguintes ${ }^{53}$.

No debate sobre a questão dos gastos públicos, a Fiesp aproximava-se da convenção neoliberal, cuja principal característica é o seu institucionalismo restrito respaldado pela teoria econômica neoclássica (ERBER, 2011). As propostas de ajuste da Fiesp e de Delfim, por exemplo, estavam embasadas no preceito de que a política fiscal, por ser fiadora da estabilidade econômica, deve estar sujeita a regras para garantir a sustentabilidade das contas do setor público. Tal preceito adveio de teorias neoclássicas reunidas no Novo Consenso Macroeconômico (NCM) (ARANTES e LOPREATO, 2017).

Ademais, as fatos narrados acima demonstram que o tipo de restrição institucional implementada pela lei do Teto de Gastos ${ }^{54}$, aprovada pelo governo Michel Temer e que congela os gastos públicos por vinte anos, já estava presente, sem a mesma radicalidade, na agenda nacional há mais de uma década e 
contava com o apoio entusiasmado da Fiesp. Não custa lembrar que Delfim e a Fiesp também participaram da formulação do "Uma Ponte para o futuro", no qual constava a lei do Teto.

Apesar de sua aproximação com o neoliberalismo no que tange à questão fiscal, a federação paulista não adere de forma irrestrita a esse padrão de comportamento e compreensão da realidade.

Em abril de 2005, a Fiesp - em parceria com a CNI, centrais sindicais de trabalhadores, como a CUT e a Força Sindical, e algumas entidades acadêmicas, como a UFRJ e a Unicamp - formulou uma proposta de ampliação da composição do Conselho Monetário Nacional (CMN), órgão responsável pela política monetária. $\mathrm{O}$ movimento visava garantir a presença de representantes do setor produtivo no colegiado, de modo a se equilibrar a busca pela estabilidade monetária com a valorização da produção e da renda ${ }^{55}$. A proposta foi aprovada no Conselho de Desenvolvimento Econômico e Social (CDES), em meio a uma tensa discussão entre, de um lado, Armando Monteiro da CNI e Paulo Skaf da Fiesp e, do outro, Roberto Setúbal do Itaú. Entretanto, Lula não implementou a proposta, favorecendo à convenção neoliberal, então hegemônica (IANONI, 2018).

Em setembro de 2005, diante da contínua elevação dos juros, os presidentes da CUT, Luiz Marinho, e da Fiesp, Paulo Skaf, tentaram costurar um pacto social para evitar novas altas da Taxa Selic. O pacto duraria três anos, período no qual o setor produtivo seria submetido a controles de preços e ampliaria os investimentos; o governo reduziria a carga tributária; o setor financeiro baixaria o custo dos empréstimos; e os trabalhadores moderariam as pressões por aumentos salariais. Lula acompanhou a posição de Palocci, que foi contra o pacto, uma vez que este poderia causar altas inflacionárias devido à remarcação de preços antes de seu início e sugerir certa incapacidade do governo de sustentar a então corrente retomada do crescimento $^{56}$.

Essas articulaçôes entre o empresariado industrial e os trabalhadores organizados sugerem que estava em curso uma maior integração entre as convenções estatal-distributivista e liberal-desenvolvimentista. Contudo, havia importantes clivagens entre elas. Uma dessas clivagens dizia respeito às reformas sindical e trabalhista. Em 2005, o governo propôs a PEC $369 \mathrm{e}$ um anteprojeto de Reforma Sindical que geraram reações negativas da Fiesp e da CNI. Elas criticavam o projeto por manter a contribuição sindical obrigatória; estabelecer a obrigatoriedade de representação sindical nas empresas; e não reconhecer a legitimidade jurídica das negociações coletivas com a manutenção da arbitragem final pela Justiça do Trabalho. Já os líderes sindicais, como Luiz Marinho da CUT, ressaltavam os avanços da proposta ${ }^{57}$. 
$\mathrm{Na}$ reforma trabalhista aprovada pelo governo Temer e apoiada pela Fiesp, em 2017, as negociaçốes coletivas passaram a prevalecer sobre o legislado e se determinou o fim do imposto sindical ${ }^{58}$. Como demonstra o embate de 2005, Temer atendeu a antigos anseios do empresariado.

Importa destacar que, em um espaço de tempo de menos de um ano, a Fiesp atuou em articulaçóes que a aproximavam ora da convenção neoliberal, buscando reduzir os gastos públicos e as intervençóes estatais na economia que compreendia como excessivas; ora da convenção estatal-distributivista, buscando maior pluralidade no processo decisório da política monetária. Isto reforça o argumento de que a Fiesp tem uma agenda relativamente autônoma, construída de forma bastante pragmática.

A terceira frente de atuação crítica da Fiesp era a da política cambial. Em janeiro de 2005, uma reportagem do periódico da Fiesp expunha a insatisfação dos setores voltados à exportação e importação com a forte apreciação e volatibilidade do câmbio. O presidente da Associação de Comércio Exterior do Brasil, Benedicto Fonseca, destacava: "Se perdurar essa equação valorização da moeda + custos internos crescentes + tarifas aduaneiras decrescentes = tendência a maior vulnerabilidade externa poderão ocorrer menor crescimento das exportaçôes ou mesmo estagnação..."(REVISTA DA INDÚSTRIA, jan., 2005, p. 23). Todos os analistas consultados pela Fiesp temiam que a apreciação do câmbio, no longo prazo, gerasse um déficit comercial e, consequentemente, uma abrupta desvalorização da moeda acompanhada de pressôes inflacionárias, mas não se arriscavam a dizer qual deveria ser o patamar da taxa de câmbio para manter a estabilidade e garantir a competitividade das empresas industriais do país ${ }^{59}$.

A Fiesp formulou propostas e apontou soluções para a questão cambial.

No final de 2005, por exemplo, ela trabalhou pela aprovação de uma lei - junto ao ministro Luiz Furlan - que permitiria aos exportadores reter por mais tempo uma parte de suas divisas, com o objetivo de ajudá-los a casar o processo de internalização das divisas com o de importação de produtos e evitar perdas relativas à volatilidade e apreciação da moeda brasileira. O projeto foi aprovado ${ }^{60}$. Já em 2006, a entidade apontou a política macroeconômica chinesa, com juros a nível internacional e um câmbio depreciado, como exemplo para que o Brasil retomasse o crescimento ${ }^{61}$.

Importa destacar que, em meados dos anos 2000, o economista BresserPereira formulou o Novo Desenvolvimentismo, uma abordagem teórica cujo principal objetivo é exatamente definir uma taxa de câmbio industrial que garanta a competitividade de empresas que produzem no estado da arte internacional (BRESSER-PEREIRA, 2014). Apesar desta abordagem 
convergir com a crítica da Fiesp à política cambial, não encontramos indícios de que ela tenha influenciado as propostas da entidade nessa frente.

Além de buscar a redução das incertezas macroeconômicas, a Fiesp também atuava no plano microeconômico, com vistas a garantir maior previsibilidade em relação à concorrência que a indústria brasileira enfrentaria $^{62}$. O engajamento crítico da Fiesp diante da política externa e de comércio exterior esteve voltado para regular os termos da concorrência e das parcerias comerciais.

\section{A Fiesp e a política externa e de comércio exterior (2004-2006).}

Em dezembro de 2004, a Fiesp reclamou publicamente do presidente Lula ter reconhecido a China como uma economia de mercado, uma vez que o país asiático mantinha várias práticas de dumping. Em reunião da Coalizão Empresarial Argentina-Brasil, empresários dos dois países contestaram a estratégia do governo brasileiro de usar a política comercial para conseguir o apoio da China à entrada do Brasil no Conselho de Segurança da ONU ${ }^{63}$. As reclamaçôes dos industriais surtiram algum efeito, pois, em outubro de 2005, Lula regulamentou decretos permitindo a setores da indústria brasileira o uso de cotas e restriçôes aos importados chineses ${ }^{64}$.

A federação paulista também contestou a suposta condescendência do governo Lula diante das cotas que a Argentina impunha às importações de produtos brasileiros no âmbito do Mercosul. A Fiesp afirmou, à época, que se a Argentina não mudasse sua postura, pressionaria o governo brasileiro a rever as condições da integração sub-regional ${ }^{65}$.

A Fiesp também revelava preocupação com o andamento das relaçóes comerciais com os EUA ${ }^{66}$, que, segundo a entidade, estava sendo preterido pela Política de Cooperação Sul-sul. Carlos Cavalcanti, diretor do Departamento de Relaçôes Internacionais e Comércio Exterior (DEREX), explicitou este incômodo: "O comércio Sul-Sul deve ser complemento... desde que não se perca de vista os maiores mercados... Precisamos sentar à mesa para negociar uma Alca que interesse aos 34 parceiros... é preciso abandonar a ideologia que contamina as discussões" (REVISTA DA INDÚSTRIA, mai., 2005, p. 43-44). O editorial da Revista da Indústria de agosto de 2006 reforçava esse discurso, ao destacar, com certa ironia, que o governo Lula dedicara-se em demasia a "... algo definido pelo atual Itamaraty como eixo Sul-Sul" e com "... timidez aos dois principais players do mercado mundial: os EUA e a União Europeia” (REVISTA DA INDÚSTRIA, ago., 2006, p. 16). A entidade paulista vislumbrava uma saída para a "politização" da política comercial a partir de formulação de uma "diplomacia empresarial”, sem a participação 
do governo, voltada para acordos setoriais, sobretudo, com o empresariado estadunidense ${ }^{67}$. A Fiesp abriu, em 2006, um escritório em Washington, para negociar tanto com órgáos oficiais quanto com o setor privado ${ }^{68}$.

Ao longo de 2006, a Federação elaborou uma agenda mais propositiva para a política de comércio exterior. No centro desta agenda estava a proposta de formação de uma agência de comércio exterior, vinculada à Presidência da República, nos moldes da United States Trade Representative (USTR) dos EUA. A ideia era que a Câmara de Comércio Exterior (CAMEX), ligada ao Ministério do Desenvolvimento, assumisse esse papel e a ela fosse concedido um status de ministério. O objetivo central da proposta era, mais uma vez, atenuar a "ideologização" da política comercial promovida pelo Itamaraty ${ }^{69}$.

As críticas que a Fiesp endereçava à política de cooperação Sul-Sul convergiam com as formuladas pelo PSDB, cujas ideias estavam no cerne da convenção neoliberal. Este fato tornou-se mais explícito, em 2016, quando José Serra (PSDB-SP) assumiu o cargo de chanceler do governo Temer e prometeu desmontar a política de cooperação Sul-Sul ${ }^{70}$.

Apesar das divergências com o governo Lula, durante a crise do mensalão, em 2005, a Fiesp não encampou as críticas da oposição e clamou pela reforma política como solução ${ }^{71}$. Creditamos essa postura à retomada das políticas industriais, com a Política Industrial, Tecnológica e de Comércio Exterior (PITCE), de 2004 (ERBER, 2011); à abertura do governo para o diálogo com as organizaçóes industriais, que tinham assento permanente no $\mathrm{CDES}^{72}$; e, por fim, aos índices econômicos que apontavam, como sublinhou Ianoni (2018), para uma retomada mais consistente do crescimento.

\section{A AGENDA FIESP E O SEGUNDO MANDATO DE LULA: A LUTA PELAS REFORMAS E OBSESSÃO PELO CRESCIMENTO (2007-2008)}

Entre 2005 e 2006, Guido Mantega e Dilma Rousseff substituíram, respectivamente, Palocci e Dirceu nos comandos do Ministério da Fazenda e na Casa Civil. Rousseff e Mantega, economistas mais próximos do estatal distributivismo, buscaram modificar a correlação de forças no governo, que passou a ter uma maior preocupação com o crescimento econômico e com a questão social.

Quando reeleito no final de 2006, Lula da Silva prometeu acelerar o crescimento, mantendo a responsabilidade fiscal ${ }^{73}$.

A entrevista que Skaf concedeu ao periódico da Fiesp, no início de 2007, seguiu a mesma linha do discurso do presidente da República. Skaf criticou a ideia, à época predominante no Brasil, de que era necessário 
optar entre crescimento ou estabilidade: " $A$ verdadeira desestabilização boje é o não-crescimento" (REVISTA DA INDÚSTRIA, jan., 2007, p. 19). Ele destacou também a forte articulação que a Fiesp alcançara junto ao legislativo e ao executivo e reforçou o seu discurso político-ideológico integrador: "A Fiesp... hoje não defende os interesses da indústria de São Paulo, ela defende os interesses do Brasil!... Temos um entrosamento muito forte e produtivo com o Congresso Nacional...” (REVISTA DA INDÚSTRIA, jan., 2007, p. 17). Em busca de legitimar sua agenda liberal-desenvolvimentista, a Fiesp descrevia suas alianças políticas como um jogo de ganha-ganha e não como um processo eivado de clivagens políticas.

No início de 2007, a Fiesp passou a enfatizar a importância dos investimentos públicos em infraestrutura para garantir a sustentação do crescimento $^{74}$. Por isso, a entidade reagiu com grande entusiasmo ao anúncio do Plano de Aceleração do Crescimento (PAC): “... o PAC anunciado pelo presidente Lula no final de janeiro merece total aprovação. Não importa que não tenham sido incluidas... o esperado choque de gestão e de contenção dos gastos públicos. Estas e outras grandes açôes fundamentais... continuarão sendo cobradas”(REVISTA DA INDÚSTRIA, fev., 2007, p. 12).

Passado o entusiasmo inicial com o Plano, a Fiesp voltou a reivindicar reformas.

No âmbito da política monetária, retomou as pressóes para a ampliação da participação do setor produtivo no Conselho Monetário Nacional $(\mathrm{CMN})^{75}$ e criticou a lenta queda dos juros a partir da contestação de relatório do Copom $^{76}$. No que tange à política cambial, a Fiesp reconhecia que as reclamações dos setores mais prejudicados pela apreciação ecoavam no vácuo porque o Brasil vivia um cenário econômico extremamente favorável: a economia crescia, havia um elevado saldo na balança comercial e um montante significativo de reservas internacionais, a inflação era declinante; e estávamos próximos de conquistar o grau de investimento ${ }^{77}$.

A federação paulista criticava também a ausência das reformas de estruturais no $\mathrm{PAC}^{78}$. No que tange à previdência, por exemplo, a entidade industrial contestou o discurso do novo ministro, Luiz Marinho, que defendia que as regras da nova previdência só poderiam valer para quem ainda não tinham entrado no mercado de trabalho. A Fiesp argumentava que, se a perspectiva do ministro fosse adotada, a mudança só teria algum impacto nas contas públicas em 30 ou 40 anos $^{79}$.

Nas políticas externa e comercial, a Fiesp demonstrava preocupação com a continuidade de Celso Amorim no Ministério das Relações Exteriores, e, portanto, com a permanência das diretrizes da política sul-sul nas relaçốes comerciais. Contudo, assumindo uma postura conciliadora, típica do 
pragmatismo da Fiesp, a Revista da Indústria publicou um artigo escrito por assessores de Samuel Pinheiro Guimarães, então secretário-geral de relaçôes exteriores, no qual as diretrizes da política comercial eram justificadas. $\mathrm{O}$ artigo sublinhava que o grande avanço nas parcerias com os países em desenvolvimento se dava pelo fato de que com eles as negociações avançavam sem maiores imposiçóes de regras que extrapolam o livre mercado, pois ambas as partes reconheciam a necessidade de dar acesso efetivo a seus mercados ${ }^{80}$.

Portanto, no que tange ao modelo de reforma da previdência e aos rumos das políticas externa e comercial, havia claros conflitos entre o liberal-desenvolvimentismo da Fiesp e o estatal-distributivismo de setores do governo. Entretanto, estes conflitos eram conduzidos de forma bastante moderada.

O mesmo não pode ser dito em relação à mobilização da Fiesp, em 2007, contra a renovação da CPMF. No editorial "Xô CPMF; Chega de Impostos", a Fiesp afirmou que tal imposto era uma expressão dos abusos do Estado contra o contribuinte. Como solução para evitar o aumento de impostos, a organização voltou a evocar a melhoria na gestão pública e o combate à corrupção ${ }^{81}$. A Fiesp argumentava que os principais “vilóes”, responsáveis pelo aumento da carga tributária, eram o funcionalismo público, a previdência e os juros ${ }^{82}$. A campanha contra o aumento de impostos, na qual a Fiesp atuou através de lobby no congresso, foi bem sucedida e a CPMF foi vetada no fim de $2007^{83}$.

Em 2008, a Fiesp, em consonância com o discurso internacional, demonstrou empolgação com a ascensão do BRIC (Brasil, Rússia, Índia e China) ${ }^{84}$. Contudo, em uma carta aos leitores da revista, Skaf sublinhava que, apesar de ter o maior potencial energético, o Brasil continuava a acumular as menores taxas de crescimento entre os quatro países. Para ele, a razão para tal atraso estava na forma pouco efetiva com que o Brasil manejava as políticas monetárias e cambiais, em oposição aos outros três países, e na lentidão com que caminhavam as reformas estruturais, entendidas como necessárias ao crescimento $^{85}$.

Ao longo do ano de 2008, a organização voltou a atuar no congresso para convencer os parlamentares a aprovar uma reforma capaz de simplificar o sistema tributário e, ao mesmo tempo, diminuir o montante da carga tributária $^{86}$. Junto com a questão da reforma, a Fiesp discutia a nova política industrial proposta pelo governo, a Política de Desenvolvimento Produtivo (PDP). Apesar dos pontos positivos da política, como os incentivos para a indústria aumentar significativamente a participação do seu investimento no PIB, os especialistas e empresários consultados pela Fiesp demonstravam temor de que os esforços de expansão fossem solapados pela constante apreciação cambial ${ }^{87}$. 
A análise do comportamento da Fiesp até a metade do segundo mandato de Lula revela, então, uma ambiguidade constante. A federação paulista pendulava, com relativa autonomia, entre articulaçóes desenvolvimentistas, que visavam à redução do patamar dos juros, e articulações mais liberais, que buscavam implementar uma política de austeridade fiscal permanente e uma política comercial que privilegiasse os EUA e a $\mathrm{UE}^{88}$.

Entretanto, com a eclosão da crise financeira internacional, a Fiesp moderou suas críticas às políticas externa e comercial e aproximou sua agenda, com maior clareza, da convenção estatal-distritivista.

\section{A Fiesp, a crise financeira internacional e o (quase) pacto socialdemocrata}

No final de 2008, em meio à eclosão da crise financeira internacional, a Fiesp e a CUT anunciaram um pacto de classes em prol do desenvolvimento. Tal pacto retomava a reivindicação, lançada pela primeira vez em 2005, de expansão da participação do setor produtivo, trabalhadores e indústria, no CMN, que visava superar o uso da elevação dos juros como o único instrumento para garantir a estabilidade monetária. Para as duas organizaçóes, o controle da inflação poderia ocorrer por meio da expansão do investimento industrial e da moderação das demandas salariais. Por outro lado, os conflitos se mantinham. A CUT desejava discutir a redução da jornada de trabalho, sem perdas salariais. Já a Fiesp, visava a uma maior flexibilização das leis trabalhistas. As duas organizaçóes montaram um grupo de trabalho para avançar nas discussões ${ }^{89}$.

Em 2009, para enfrentar os impactos da crise financeira internacional no setor industrial, que dispensava um número crescente de trabalhadores, a Fiesp voltou a se reunir com representantes de diversos sindicatos patronais e de trabalhadores. Dessa vez, a articulação se deu com a Força Sindical, a CGT e a UGT. As principais soluçóes propostas foram a redução da jornada de trabalho, com redução de salários, mas atrelada a cursos de qualificação gratuitos, a concessão de férias coletivas e o uso de banco de horas ${ }^{90}$. Em relação às medidas estruturais, as organizaçóes concordaram em pressionar o governo em prol da redução da carga tributária, da implementação de subsídios e de uma queda mais agressiva da taxa Selic e dos spreads bancários ${ }^{91}$.

As negociações entre industriais e trabalhadores em prol da superação da crise não foram os únicos sinais de uma integração mais sólida entre as convenções liberal-desenvolvimentista e estatal-distributivista. No final de 2008, em meio as crescentes preocupaçóes com os efeitos da crise financeira norte-americana, o governo Lula buscou o apoio da Fiesp para avançar sua política comercial. Importa lembrar que a federação paulista vinha lutando 
por este espaço desde 2004, quando intensificou suas missóes diplomáticas no exterior e passou a receber comitivas oficiais de outros países na sua sede.

Em outubro de 2008, Lula realizou um encontro oficial com o presidente do Peru na sede da Fiesp. Nas reunióes comerciais, estiveram em pauta, sobretudo, a expansão de investimentos de empresas brasileiras, como a Vale e a Eletrobrás, no Peru, o que visava fortalecer a políticade multinacionalização das grandes companhias nacionais implementada pelo governo e apoiada pela federação paulista ${ }^{92}$. $\mathrm{Na}$ mesma linha se deram as negociações entre a presidente Cristina Kirchner, da Argentina, e o presidente brasileiro, no Encontro Empresarial Brasil-Argentina, sediado pela Fiesp ${ }^{93}$. Em meados de 2009, a Fiesp exaltava as potencialidades da política de expansão das empresas nacionais na América Latina, reforçada pelo PDP, e o papel diplomático do presidente Lula na internacionalização das empresas ${ }^{94}$.

Ao longo de 2009 e 2010, Lula continuou a receber comitivas oficiais na Fiesp - recebeu as do Peru, do Chile, da Colômbia, dos Países Baixos e da Itália - e a entidade já vislumbrava a consolidação do Brasil como um player relevante no comércio internacional ${ }^{95}$.

A verdade é que a crise financeira, que impactou no primeiro momento, principalmente, o mundo desenvolvido, fortaleceu a política de cooperação sul-sul do governo e a Fiesp, pragmaticamente, aderiu a ela. Anos depois, em uma entrevista ao site $U O L$, Skaf reconheceria que o estilo de Lula governar - o fato de ter ido à Fiesp receber lideranças de outros países - facilitava a relação entre o governo e o empresariado, algo que não ocorreu no governo de Dilma ${ }^{96}$.

O clima de otimismo e cooperação entre os industriais paulistas e o governo se expressou nas eleiçóes. Mais precisamente, no apoio que Lula, Dilma e o PT, mesmo tendo um candidato próprio na disputa, deram à candidatura de Skaf ao governo de São Paulo ${ }^{97}$. Lula chegou mesmo a cogitar o lançamento de uma chapa formada por Ciro Gomes e Paulo Skaf para o governo paulista ${ }^{98}$.

É na esteira do relativo sucesso do pacto lulista - segundo Secco (2011) e Singer (2012), uma socialdemocrata à brasileira - que Dilma Rousseff chegou à presidência da república. Isto não significa, entretanto, que as tensões entre o liberal-desenvolvimentismo e o estatal-distributivismo tinham desparecido. $\mathrm{Na}$ esteira do fortalecimento do Lulismo, enquanto os sindicatos buscavam a redução da jornada de trabalho e o governo discutia uma proposta que tornaria obrigatório o pagamento de lucros e resultados aos trabalhadores em todas as empresas, a Fiesp se opunha às duas propostas e tentava frear o ímpeto reformista do estatal-distributivismo ${ }^{99}$. 
Portanto, o comportamento da Fiesp ao longo do governo Lula expressa claramente o movimento pendular burguês descrito por Singer (2015). Contudo, neste período, o movimento pendular era feito, quase sempre, de forma moderada e só se acelerava quando entrava na agenda a questão do aumento da carga tributária, como vimos no caso da CPMF.

\section{CONCLUSÃO: A HIPÓTESE DO "EFEITO TÚNEL ÀS AVESSAS"}

A Fiesp tem um agenda liberal-desenvolvimentista concreta para o país. Assim, no âmbito da macroeconomia, a entidade visa à adoção de taxas de juros moderadas, de um câmbio competitivo e uma austeridade fiscal permanente. No que tange às reformas estruturais, com vista a uma redução drástica nos gastos públicos e na carga tributária, a organização propõe e apoia reformas trabalhistas, previdenciárias e tributárias dotadas de viés neoliberal. Ainda em relação ao controle dos gastos públicos, a federação paulista propóe um "choque de gestão" para aumentar a eficiência do gasto e melhorar a qualidade dos serviços. No campo da política comercial, as relaçóes sul-sul devem ser complementares e o eixo central desta política deve ser o estreitamento das relaçóes com os EUA e a Europa.

Para implementar essa agenda, a federação paulista atua com grande pragmatismo e relativa autonomia. Durante os governos do PT, quando reivindicava a redução dos juros, a Fiesp se aliava às bases da convenção estataldistributivista, especialmente aos sindicatos de trabalhadores e intelectuais progressistas. Quando visava à redução da carga tributária, dos gastos sociais e da intervenção do Estado nas relaçóes entre capital e trabalho, a entidade se alinhava com as bases da convenção neoliberal, sobretudo aos economistas ortodoxos, financistas e setores da alta classe média urbana. A cada mudança no cenário político e econômico, o movimento pendular da Fiesp se acentuava para um lado ou para o outro. Entre 2008 e 2009, no contexto inicial da crise financeira internacional, a Fiesp aderiu à estratégia de cooperação sul-sul do governo Lula e iniciou um intenso diálogo com sindicatos de trabalhadores. Já entre 2014 e 2015,diante do forte crescimento do emprego, da queda das taxas de lucro e do avanço da desindustrialização, a Fiesp fez o movimento contrário, se afastando do governo Dilma e aderindo à crítica virulenta que as bases do neoliberalismo dirigiam a ele.

Esta conclusão reforça a tese de Bianchi (2015) de que o apoio da Fiesp ao impeachment era uma decisão racional, que atendia aos interesses de curtoprazo da entidade, sobretudo à parte da sua agenda voltada para as reformas estruturais, e de que os industriais paulistas não têm partido e agem com relativa autonomia para alcançar seus objetivos. 
Por fim, a partir do movimento pendular realizado pela Fiesp entre o final do governo Lula e o impeachment de Dilma, gostaríamos de formular uma hipótese sobre o que ocorreu no Brasil na última década.

Por razóes estruturais e a despeito das taxas de crescimento da economia não terem alcançado níveis muito elevados, entre 2004 e 2014, os salários reais cresceram, continuamente, acima do crescimento da produtividade. Essa "revolução indesejada" - termo cunhado por Serrano e Summa (2018) para destacar que tal dinâmica não foi planejada - fortaleceu o poder de barganha dos trabalhadores, em geral, e dos menos qualificados, em particular, e, consequentemente, reduziu o poder do capital em controlar o conflito distributivo. O aumento dos salários mais baixos, sobretudo devido à política de valorização do salário mínimo implementada desde o governo Lula, somou-se à redução significativa das taxas de desemprego no primeiro governo Dilma, o que gerou a chamada "inflação de serviços” e impactou crescentemente a qualidade de vida da classe média (CARVALHO, 2018).

Com a relação à indústria, a queda das exportaçóes industriais, que começara em 2007, foi compensada pelo crescimento do mercado interno até 2011. A partir deste momento, a manutenção do câmbio apreciado, a despeito das tentativas do governo Dilma de depreciá-lo, permitiu, aos poucos, a captura do mercado interno pelas importações que, somada ao aumento dos salários acima do crescimento PIB, gerou uma redução da taxa de lucro esperada em todos os setores da economia e agravou a desindustrialização. Logo, o país voltou a crescer pouco e o pacto lulista desmoronou (BRESSER-PEREIRA, 2014).

As dinâmicas socioeconômicas geradas pelo modelo de desenvolvimento adotado por Lula e Dilma produziram um acirramento do conflito distributivo, somente percebido com a explosão das revoltas de junho de 2013 e, principalmente, com o ódio à Dilma, a Lula e ao PT expressado ao longo das campanhas eleitoral de 2014 e do impeachment, entre 2015 e 2016, e reforçado pelos vazamentos da Lava-Jato. Neste ponto concordamos mais uma vez com Bresser-Pereira que, em entrevista à Folha da São Paulo, destacara que tal ódio decorria do fato dos governos petistas terem revelado uma preferência forte e clara pelos trabalhadores e pelos mais pobres ${ }^{100}$.

Dito isto, a questão a ser respondida é: por que ninguém percebeu que estava se formando tamanha onda de ódio, que viria a dividir a sociedade? O que ocorreu para que a Fiesp, que havia homenageado Lula com um jantar em sua sede, em $2011^{101}$, cerca de cinco anos depois, sediasse um evento onde empresários empunhariam o "pixuleco", boneco de Lula vestido de presidiário $^{102}$ ? 
A nossa hipótese é que na sociedade brasileira aquilo que Hirschman e Rothschild (2013) chamaram de "efeito túnel” tem uma duração bastante limitada. Os autores afirmaram que as duas principais tarefas de um país para alcançar o desenvolvimento econômico são o crescimento e a distribuição de renda. Um país bem equipado de "efeito túnel" - mecanismo de tolerância a partir do qual o progresso alheio produz um sentimento inicial de satisfação devido à perspectiva de futuro que se avizinha para os que ainda não foram beneficiados - poderia alcançar crescimento e distribuição de forma sequencial. Primeiro um, depois o outro. Entretanto, em realidades sociais, políticas e psicológicas em que o efeito túnel fosse fraco ou inexistente, as duas tarefas teriam de ser alcançadas simultaneamente, um esforço hercúleo, mas necessário para evitar um "desastre do desenvolvimento". Segundo Hirschman e Rothschild (2013), o golpe de 1964 no Brasil, exemplo de um "desastre do desenvolvimento", deveu-se à ruptura do efeito túnel. O crescimento com parca distribuição de renda, inicialmente aceito, sem aviso prévio, desencadeou tensóes políticas que acirraram os conflitos de classe e desencadearam o golpe civil-militar.

Olhando para a presente década, parece ter ocorrido um "efeito túnel às avessas”. O país cresceu a taxas moderadas na década de 2000 e desencadeou um processo de redistribuição de renda significativo na base da pirâmide, a tal "revolução indesejada". Após a eclosão da crise financeira internacional, entre 2009 e 2012, auge do pacto lulista, o efeito túnel parecia ter se expandindo no país. Contudo,entre 2011 e 2014, a continuidade do processo redistributivo, mesmo diante da desaceleração do crescimento, parece ter dissipado o efeito túnel. Setores da classe média e do topo da pirâmide atuaram politicamente, em diversas esferas da sociedade, para pressionar o governo Dilma a desmantelar o conjunto de políticas que tinham, até então, favorecido os mais pobres no conflito distributivo (SERRANO e SUMMA, 2018). Após derrubar Dilma, Temer acelerou esse processo a partir de um conjunto de reformas estruturais. Usamos aqui o termo "efeito túnel às avessas" porque, ao contrário dos casos analisados por Hirschman e Rothschild (1973), no Brasil contemporâneo o sentimento de perda de status e inveja aplacou as classes médias tradicionais ${ }^{103}$ e os ricos. Os primeiros porque viram sua distância em relação aos mais pobres diminuir (CARVALHO, 2018). Os segundos porque, além da desaceleração do crescimento, presenciaram a queda das taxas de lucro e de seus rendimentos financeiros (BRESSER-PEREIRA, 2014).

Mas e a Fiesp? Seu comportamento pendular, mobilizado pelo pragmatismo, é sensível às conjunturas. $\mathrm{Na}$ década passada, diante do pacto lulista e da retomada do crescimento, ele pendulou moderadamente. Nesta década, 


\title{
com queda das taxas de lucro e crescente desindustrialização, ele acompa- nhou o radicalismo dos mais abastados. Resta saber se uma indústria mini- mamente sofisticada sobreviverá ao desmonte social e econômico promovido por um neoliberalismo tão radical.
}

\begin{abstract}
Notas
'Agradeço ao Instituto Nacional de Ciência e Tecnologia em Políticas Públicas, Estratégias e Desenvolvimento (INCT-PPED) por me conceder a bolsa de Pós-doutorado que deu origem a esta pesquisa; à FAPERJ e àCapes por financiá-la; aos professores Ana Célia Castro, Antonieta Leopoldi (minha supervisora) e Marcus lanoni pelo apoio à pesquisa; e ao Programa de Pós-Graduação em Ciência Política
\end{abstract} (PPGCP) da UFF por sediá-la.

${ }^{2} \mathrm{O}$ impeachment foi compreendido, por significativa parcela da sociedade, como um golpe de Estado. Embora esta questão não seja central a este texto, a seguir apresentamos fatos que corroboram a narrativa do golpe.

${ }^{3}$ A FIESP engloba, atualmente, 131 sindicatos patronais, que representam cerca 130 mil indústrias de diversos setores e diferentes portes. Disponível em: <https://bit.ly/2mnjovQ>. Acesso em: 20 mai. 2019.

${ }^{4}$ Em meados de 2013, o Valor Econômico publicou uma reportagem destacando que diversos políticos e empresários já pediam a Lula para substituir Dilma no pleito de 2014. Disponível em: https://bit. ly/2kBhxTp. Acesso em 15 abr. 2019.

${ }^{5}$ Paulo Skaf, presidente da Fiesp, comemorou a MP que anunciava a redução das tarifas em entrevista à revista ISTOÉ. Disponível em: https://bit.ly/2IJ81Oe. Acesso em 15 abr. 2019.

${ }^{6}$ Essas demandas foram expressas no documento Brasil do diálogo, da produção e do emprego, formulado em conjunto com centrais sindicais e entregue ao governo em 2011. Disponível em: https://bit. ly/2INnWey. Acesso em 15 abr. 2019.

${ }^{7}$ Em um debate entre candidatos a governador de São Paulo, Skaf chegou a dizer que votaria em Temer e não em Dilma ou no PT. Disponível em: https://bit.ly/2kx7tes. Acesso em: 15 abr. 2019.

${ }^{8}$ Dilma nomeou Joaquim Levy, um economista reconhecidamente ortodoxo, para o Ministério da Fazenda. Disponível em: https://bit.ly/2lOOzj8. Acesso em: 15 abr. 2019.

${ }^{9}$ Disponível em: https://bit.ly/2HBqmIR. Acesso em: 15 abr. 2019.

${ }^{10}$ Disponível em: https://glo.bo/2DFcdHm. Acesso em: 15 abr. 2019.

${ }^{11}$ Termo usado pelo juiz Sérgio Moro, responsável pela LJ, em artigo acadêmico sobre a ManiPulite, operação de combate à corrupção italiana que parece ter inspirado a atuação do juiz brasileiro. Disponível em: https://bit.ly/2p5pVcY. Acesso em: 21 abr. 2019.

${ }^{12}$ Um exemplo de que a $\sqcup$ agiu para derrubar Dilma Rousseff é o fato de que o juiz Sérgio Moro vazou, de forma ilegal, para a imprensa o áudio de uma conversa entre a presidente e o ex-presidente Lula, em março de 2016. O trecho divulgado induzia à interpretação de que Lula assumiria a Casa Civil para se aproveitar do foro privilegiado. Com base nesse vazamento, o STF impediu que Lula assumisse o cargo. Recentemente, a série de reportagens do The Intercept Brasil revelou conversas de procuradores e agentes da PF que tornam evidentes que a $\downarrow$ vazou apenas um pequeno trecho das muitas conversas que o ex-presidente manteve sobre a nomeação, de modo a inflamar a opinião pública contra o governo. Disponível em: https://bit.ly/2kPXS2c. Acesso em: 08 abr. 2019.

${ }^{13}$ Em 2017, o PMDB voltou a se chamar MDB. Disponível em: https://glo.bo/2oNb35r. Acesso em: 22 abr. 2019.

${ }^{14}$ Disponível em: https://bit.ly/2IKISCO. Acesso em: 22 abr. 2019.

${ }^{15}$ Disponível em: https://bit.ly/2m0ayDU. . Acesso em 30 abr. 2019.

${ }^{16}$ Disponível em:https://glo.bo/1JQLUcj. Acesso em: 30 abr. 2019.

${ }_{17}$ Disponível em: https://glo.bo/2llApAn. Acesso em: 30 abr. 2019

${ }^{18}$ Disponível em: https://bbc.in/2m9WkjX. Acesso em: 01 abr. 2019.

${ }^{19} \mathrm{Na}$ nota publicada pela Fiesp e pela Firjan, no início de agosto, as duas entidades incitavam o governo à agir em prol da manutenção do grau de investimento.Disponível em: https://glo.bo/1JQLUcj. Acesso em 30 abr. 2019. 
${ }^{20}$ Disponível em: https://bit.ly/2k6ADRc>. Acesso em 25 abr. 2019.

${ }^{21}$ Disponível em: https://glo.bo/1MKCC1i>. Acesso em 25 abr. 2019.

22 Disponível em: https://bit.ly/2uxHftl>. Acesso em 01 abr. 2019.

${ }^{23}$ Disponível em: https://bit.ly/2IKISCO e https://bit.ly/2kHDpMW. Acesso em: 01 mai. 2019.

${ }^{24}$ Disponível em: https://bit.ly/2IKISCO. Acesso em: 30 abr. 2019.

${ }^{25}$ Disponível em: https://glo.bo/2maBzVj. Acesso em: 30 abr. 2019.

${ }^{26}$ Disponível em: https://bit.ly/2zKMkAh. Acesso em: 01 mai. 2019.

${ }^{27}$ Disponível em: https://bit.ly/2ma0zvS. Acesso em; 01 mai. 2019.

${ }^{28}$ Disponível em: https://bit.ly/22LFx4N. Acesso em: 03 mai. 2019.

${ }^{29}$ Disponível em: https://bit.ly/2keVSjX. Acesso em: 03 mai. 2019.

${ }^{30}$ Disponível em: https://bit.ly/1T8fkEE. Acesso em: 23 mar. 2019.

${ }^{31}$ Disponível em: https://bit.ly/2mjGfbE. Acesso em: 10 mai. 2019.

32 Disponível em: https://bit.ly/2mchttM. Acesso em: 10 mai. 2019.

${ }^{33}$ Disponível em: https://bit.ly/2kidY4s. Acesso em: 23 mar. 2019.

${ }^{34}$ A origem intelectual desta convenção remonta a um projeto formulado, ao longo dos anos de 1980, por setores da alta burocracia do Estado, sobretudo, do BNDES, e que recebera a alcunha de "integração competitiva". Este visava à inserção ativa do Brasil no cenário da globalização, através da capacitação das empresas nacionais para a competição (SALLUM JR. \& GOULART, 2016).

35 Disponível em: https://bit.ly/2mcr7wq. Acesso em: 20 mai. 2019.

${ }^{36}$ Disponível em: https://bit.ly/2l3idkP. Acesso em: 20 mai. 2019.

37 Disponível em: https://bit.ly/2l8VXWF. Acesso em: 20 mai. 2019.

38 Disponível em: https://glo.bo/2mwUiuo. Acesso em: 20 mai. 2019.

${ }^{39}$ Disponível em: https://bit.ly/2mxKikA. Acesso em 20 mai. 2019.

${ }^{40}$ Disponível em: https://bit.ly/2m6BfqQ. Acesso em 20 mai. 2019.

${ }^{41}$ Disponível em: https://bit.ly/2m6BfqQ., https://bit.ly/2m4aeEe, e https://glo.bo/2kz8vqe. Acesso em: 20 mai. 2019.

${ }^{42}$ Disponível em: https://bit.ly/2kX9Zec. Acesso em: 20 mai. 2019.

${ }^{43}$ Disponível em: https://bit.ly/2mwy8Zc. Acesso em: 20 mai. 2019.

${ }^{44}$ Disponível em: https://bit.ly/2l0nUjx. Acesso em: 20 mai. 2019.

${ }^{45}$ A ideia embedded autonomy foi utilizada por Evans para falar da capacidade da burocracia pública de alguns países em se articular com o setor privado, sem ser cooptada por este, para formular e implementar políticas industriais.

${ }^{46}$ Revista da Indústria. Dezembro, 2004.

${ }^{47}$ As críticas que Delfim Netto endereçava ao governo Cardoso convergiam com as críticas dos quadros liberal-desenvolvimentistas do próprio governo (SALLIM Jr., 1999).

${ }^{48}$ Disponível em: https://bit.ly/38EiaiW. Acesso em 20 mai. 2019.

49 RIOS, Manuela. O preço do crescimento. Revista da Indústria. Dezembro, 2004.

50 SILVA, Marco Antônio. Selic: o céu é o limite? Revista da Indústria. Abril, 2005.

51 SALEM, Armando. Brasil: da derrama à Medida Provisória 232. Revista da Indústria. Fevereiro, 2005.

${ }^{52}$ Disponível em: https://bit.ly/2necwBo. Acesso em 02 jun. 2019.

${ }^{53}$ OLIVEIRA, Raymundo. A meta é a eficiência. Revista da Indústria. Julho, 2005.

${ }^{54}$ Disponível em: https://bit.ly/2APkjqS. Acesso em 02 jun. 2019.

${ }^{55}$ AYMORÉ, Artur. Abaixo a autocracia. Revista da Indústria, abril, 2005.

${ }^{56}$ Disponível em: https://bit.ly/2mPLu2T. Acesso em 01 jun. 2019.

${ }^{57}$ IGNÁCIO, Valéria. O risco da separação. Revista da Indústria, abril, 2005.

${ }^{58}$ Disponível em: https://bit.ly/2mntVaE. Acesso em: 20 jun. 2018.

${ }^{59}$ TOLEDO, Rubens. A insustentável leveza. Revista da Indústria, jan., 2005. 
${ }^{60}$ CUNHA, Fernanda. Rumo à Modernidade. Revista da Indústria, set., 2005.

61 SALEM, Armando. Dr. Meirelles, o yuan e o nosso Dr. real. Revista da Indústria, out., 2006.

${ }^{62}$ A redução das incertezas micro e macroeconômicas caracterizou a atuação do empresariado industrial brasileiro após a abertura comercial e financeira (FERRAZ ET AL.,1999).

${ }^{63}$ IGNÁCIO, Valéria. Forças e Fraquezas do dragão. Revista da Indústria, dez., 2004.

${ }^{64}$ CUNHA, Fernanda. Em defesa da indústria. Revista da Indústria, out., 2005.

${ }^{65}$ CUNHA, Fernanda. Tremores no Mercosul. Revista da Indústria, jan., 2005.

${ }^{66}$ RIOS, Manuela. Por que não ampliar negócios com os EUA? Revista da Indústria, mai., 2005.

${ }^{67}$ TACHINARDI, Maria Helena. Muita ideologia, poucos resultados. Revista da Indústria, ago., 2006.

${ }^{68}$ ROCHA. Fábio. Fiesp em Washington. Revista da Indústria, ago., 2006.

${ }^{69}$ RIOS, Manuela. Por que não ampliar negócios com os EUA? Revista da Indústria, mai., 2005.

${ }^{70}$ Disponível em: https://bit.ly/32v6AEq. Acesso em: 25 jun. 2019.

${ }^{71}$ REVISTA DA INDÚSTRIA. A saída é a reforma. Revista da Indústria, jul., 2005.

${ }^{72}$ Guido Mantega, por exemplo, ao assumir o BNDES deu uma entrevista exclusiva à Revista da Indústria. Disponível em: MELLO, Hélio Campos. Dinheiro para todo mundo. Revista da Indústria, mai., 2005.

${ }^{73}$ Disponível em: https://glo.bo/2IKYk2r. Acesso em: 25 jun. 2019.

${ }^{74}$ CUNHA, Fernanda. Caminhos para o crescimento. Revista da Indústria, jan., 2007.

${ }^{75}$ Revista da Indústria. Mudança de paradigma da macroeconomia. Abr., 2007.

${ }^{76}$ CASTRO, Gleise. Dois pesos, duas medidas. Revista da Indústria, abr., 2007.

77 TACHINARDI, Maria Helena. Gritos no Vácuo. Revista da Indústria, mai., 2007.

${ }^{78}$ SOLIANI, André. E ninguém no governo falou das reformas. Revista da Indústria, fev., 2007.

${ }^{79}$ SOLIANI, André. Reforma polêmica. Revista da Indústria, abr., 2007.

${ }^{80}$ SALEM, Armando. Sob a mesma direção. Revista da Indústria, jan., 2007.

81 SALEM, Armando. "Xô CPMF; Chega de Impostos". Revista da Indústria, jun., 2007.

82 KASSAl, Lúcia. O governo na contramão. Revista da Indústria, jun., 2007.

${ }^{83}$ Disponível em: https://bit.ly/2noBJsG. Acesso em: 01 jul. 2019.

${ }^{84} \mathrm{Na}$ reportagem não se menciona a África do Sul. Portanto, Bric, não Brics.

${ }^{85}$ SKAF, Paulo. O B de "BRIC". Revista da Indústria, fev., 2008.

${ }^{86}$ Ramon, Jander. Hora de reformar. Revista da Indústria, jun., 2008.

${ }^{87}$ MELLONI, Eugênio. Só política não basta. Revista da Indústria, jun., 2008.

${ }^{8}$ Para Bresser-Pereira (2014), tanto liberais quanto desenvolvimentistas ignoravam o problema da apreciação cambial.

${ }^{89}$ RAMON, Jander. Brasil a quatro mãos. Revista da Indústria, set., 2008.

${ }^{9}$ CAVALCANTI, Simone. Empregos sob ataque. Revista da Indústria, fev., 2009.

${ }^{91}$ VELLOSO, Thiago. Inimigo público número 1. Revista da Indústria, fev., 2009.

${ }^{92}$ VICENTE, Adilson. Embaixada de negócios. Revista da Indústria, out., 2008.

${ }^{93}$ CAVALCANTI, Simone. Mão Dupla. Revista da Indústria, abr., 2009.

${ }^{94}$ CAVALCANTI, Simone. Rumo à América Latina. Revista da Indústria, mai., 2009.

${ }^{95}$ FONSECA, Fátima. Diplomacia Empresarial. Revista da Indústria, jun., 2010.

${ }^{96}$ Disponível em: https://bit.ly/2o6VIMZ. Acesso em: 10 ago. 2019.

${ }^{97}$ Disponível em: https://bit.ly/2mBa73H. Acesso em: 01 ago. 2019.

${ }^{98}$ Disponível em: https://bit.ly/2ISrnRx. Acesso em: 01 ago. 2019.

${ }^{99}$ SAAD, Théo. Abaixo o intervencionismo. Revista da Indústria, abr., 2010.

${ }^{100}$ Disponível em: https://bit.ly/2nwtCLe. Acesso em: 02 Set. 2019.

101 Disponível em: https://bit.ly/2ojAQ56. Acesso em: 02 Set. 2019.

102 Disponível em: https://glo.bo/2kJv77j. Acesso em: 02 Set. 2019. 


\begin{abstract}
${ }^{103}$ O enfrentamento entre o governo Dilma e as classes médias tradicionais expressou-se simbolicamente antes mesmo da campanha do impeachment, nas críticas, por exemplo, dos militares às Comissões da Verdade, instauradas para esclarecer crimes de agentes do Estado contra os direitos humanos durante a ditadura, e dos médicos e de suas associações de classe ao Programa Mais Médico, que trouxe médicos estrangeiros, sobretudo cubanos, para trabalharem em municípios distantes dos grandes centros e carentes de atendimento.
\end{abstract}

\section{Referências}

ARANTES, Flávio e LOPREATO, Francisco. O NOVO CONSENSO EM MACROECONOMIA NO BRASIL: A POLÍTICA FISCAL DO PLANO REALAO SEGUNDO GOVERNO LULA. Rev. Econ. Contemp., v. 21, n. 3, p. 1-34, set-dez/2017.

BASTOS, Pedro P. Z. Ascensão e crise do governo Dilma Rousseff e o golpe de 2016: Poder estrutural, contradição e ideologia. Rev. Econ. Contemp., núm. esp., 2017.

BIANCHI, Álvaro. Por que a Fiesp apoia o impeachment.Blog Junho,2015. Acesso em: 10 set. 2018. Disponível em: <https://bit. ly/1T8fkEE>.

O ministério dos industriais: a Federação das Indústrias do Estado de São Paulo na crise das décadas de 1980 e 1990.2004. Tese (Doutorado em Ciências Sociais) - Departamento de Ciência Política do Instituto de Filosofia e Ciências Sociais, da Universidade Estadual de Campinas, Campinas.

BOSCHI, Renato. Elites industriais e democracia: hegemonia burguesa e mudança política no Brasil. Rio de Janeiro: Graal, 1979.

BRESSER-PEREIRA, Luiz Carlos. A construção política do Brasil: sociedade, economia Estado desde a Independência. São Paulo: Editora 34, 2014.

CARVALHO, Laura. Valsa brasileira: do boom ao caos econômico. São Paulo: Todavia, 2018.

DINIZ, Eli. Empresário, Estado e capitalismo no Brasil (1930-1945). Rio de Janeiro: Paz e Terra, 1978. e BOSCHI, Renato. Empresário, interesses e mercado: dilemas do desenvolvimento no Brasil. Belo Horizonte: Editora UFMG; Rio de Janeiro: IUPERJ, 2004.

ERBER, Fábio Stefano. As convenções de desenvolvimento no Governo Lula: um ensaio de economia política. Revista de EconomiaPolítica, v. 31, n. 1, p. 31-55, jan./ mar. 2011.

The Brazilian development in the nineties - myths, circles and structures. Nova Economia, v. 12, n. 1, 2002.

EVANS, Peter. Autonomia e Parceria: Estado e Transformação Industrial. Rio de Janeiro: Editora da UFRJ, 2004.

FERRAZ, João C. et al. Incerteza, adaptação e mudança: a indústria brasileira entre 1992 e 1998. Boletim de Conjuntura da Universidade Federal do Rio de Janeiro, Rio de Janeiro, 1999.

FIESP. Revista da Indústria. São Paulo, 2004-2010.

HIRSCHMAN, Albert e ROTHSCHILD, Michael. The changing tolerance for income inequality in the course of Economic development. In: ADELMAN, Jeremy (Ed.). The Essential Hirschman. Princeton and Oxford: Princeton University Press, 2013, 74-101. IANONI, Marcus. Estado e coalizões no Brasil (2003-2016): socialdesenvolvimentismo e neoliberalismo. $1^{\mathrm{a}}$ ed. Rio de Janeiro: Contraponto, 2018. LEOPOLDI, Maria A. P.Política e interesses: as associações industriais, a política econômica e o Estado na industrialização brasileira. São Paulo: Paz e Terra, 2000. 
NIEDERLE, Paulo André. Economia das Convenções: subsídios para uma sociologia das instituições econômicas. Ensaios FEE, Porto Alegre, v. 34, n. 2, p. 439-470, dez. 2013.

SALLUM JR., Brasilio. O Brasil sob Cardoso: neoliberalismo e desenvolvimentismo. Tempo Social: Revista de Sociologia da USP, v. 11, n. 2, 1999.

. O desenvolvimentismo e o Estado brasileiro contemporâneo. In: Bresser-Pereira, Luiz Carlos (Org.). O Que Esperar do Brasil? Rio de Janeiro: Editora FGV, 2013,61-72. e GOULART, Jefferson. O Estado brasileiro contemporâneo: liberalização econômica, política e sociedade nos governos FHC e Lula. Rev. Sociol. Polit., v. 24, n. 6o, p. 115-135, dez. 2016.
SECCO, Lincoln. História do PT. Cotia: Ateliê, 2011

SERRANO, Franklin e SUMMA, Ricardo. CONFLITO DISTRIBUTIVO E O FIM DA "BREVE ERA DE OURO" DA ECONOMIA BRASILEIRA. Novos estudos. CEBRAP. São Paulo. v. 37 n.02. 175-189. mai.-ago. 2018. SINGER, A. Cutucando onças com varas curtas. Novos Estudos, n.102, julho de 2015. O lulismo em crise: um quebracabeça do período Dilma (2011-2016). São Paulo: Companhia das Letras, 2018. Os sentidos do lulismo: reforma gradual e pacto conservador. São Paulo: Companhia das Letras, 2012.

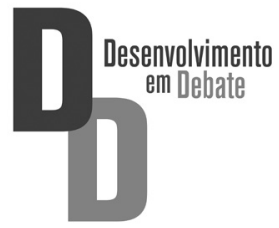

